\title{
Effects of Sequential Trinexapac-Ethyl Applications and Traffic on Growth of Perennial Ryegrass (Lolium perenne L.)
}

\author{
Rahim Amiri-Khah ${ }^{1}$, Nematollah Eetemadi ${ }^{1 *}$, Ali Nikbakht ${ }^{1}$, and Mohammad Pessarakli ${ }^{2}$ \\ ${ }^{1}$ Department of Horticultural Science, College of Agriculture, Isfahan University of Technology, 84156-83111, Isfahan, Iran \\ ${ }^{2}$ School of Plant Sciences, University of Arizona, USA
}

\begin{abstract}
Mowing turfgrasses, especially fast growing species like perennial ryegrass, is one of the most time and money consuming tasks of their management. Trinexapac-ethyl (TE) is a popular plant growth regulator used to reduce mowing requirements, improve stress tolerance, and enhance turf quality. This study was conducted to investigate the effect of TE rate and frequency of applications on growth response and traffic tolerance of perennial ryegrass. The experiment was a split-plot laid out in a randomized complete block (RCB) design with three replications. TE was applied to main plots at $0.00,0.25$, and $0.50 \mathrm{~kg}$ a.i. $\mathrm{ha}^{-1}$. Application pattern included an initial application, followed by two sequential applications at 6-wk intervals. Traffic treatment was applied to subplots with a cleated roller. Results demonstrated that TE consistently reduced vertical shoot growth, clippings dry weight, with maximum growth reduction of $59 \%$ and $65 \%$, for 0.25 and $0.50 \mathrm{~kg}$ a.i. ha ${ }^{-1}$, respectively, occurring at 2 weeks after initial TE treatment (WAT). Traffic also dramatically reduced vertical shoot growth and clippings dry weight. Overall, quality of perennial ryegrass was enhanced by sequential TE applications, however, turf quality and surface coverage reduced greatly under traffic, regardless of TE treatment. Total chlorophyll, chlorophyll $a$ and chlorophyll $b$ and total carbohydrates (TC) contents were also positively influenced following sequential TE application. Our results indicated that TE reduces mowing frequency and enhances turf quality rather than influencing traffic resistance.
\end{abstract}

Additional key words: growth rate, mowing frequency, turf quality

\section{Introduction}

Turfgrasses are the most important ground covers and they are mostly the main elements of landscape design. They cover soil surface and provide a pleasant green space. Plant growth regulators (PGRs) play a beneficial role for high maintenance turf management to reduce mowing and suppress seed head development (Watschke et al., 1992). PGRs have also been shown to affect turfgrass population dynamics and enhance the tolerance of turfgrasses to abiotic stresses (Nabati et al., 1994). One of the PGRs inhibiting cell elongation, trinexapac-ethyl, has been the most widely accepted and extensively used chemical for preparing turfgrasses for various types of stresses and improving general turf quality (McCullough et al., 2005; Richardson, 2002). TE is a foliar applied PGR that suppresses laminar cell elongation by interfering with gibberellins biosynthesis (Adams et al., 1992). TE disrupts 33-hydroxilation of $\mathrm{GA}_{20}$ to the physiologically- active $\mathrm{GA}_{1}$ in the late stages of GA biosynthesis (Rademacher, 2000; Tan and Qian, 2003).

A number of researchers have reported that TE reduced turfgrasses shoot growth, mowing requirement, and enhanced turf quality (Burpee et al., 1996; Daniels and Sugden, 1996; Ervin and Koski, 1998; McCullough et al., 2006a; McCullough, 2004). McCullough et al. (2006b) reported that applications of TE decreased clipping yield of 'TifEagle' bermudagrass (Cynodon dactylon L.). Inhibition of leaf elongation has been shown to increase mesophyll cell density and chlorophyll concentration, resulting in an overall darker green appearance of the plants and enhanced turfgrass color and quality (Ervin and Koski, 2001; Heckman et al., 2005; McCullough et al., 2006b). Color of Kentucky bluegrass (Poa pratensis

\footnotetext{
*Comesponding author: etemadin@cc.iut.ac.ir

※ Received 10 October 2014; Revised 26 January 2015; Accepted 29 January 2015.

(C) 2015 Korean Society for Horticultural Science
} 
L.) was consistently darker in TE-treated plants compared with the non-treated control (Stier and Rogers, 2001).

Qian and Engelke (1999) reported that photosynthesis rates of zoysiagrass (Zoysia matrella L.) increased in response to TE treatments. TE has been shown to reduce respiration in plants (Heckman et al., 2002). Shoot growth suppression triggered by TE encouraged photosynthate and nutrient allocation to other sink tissues such as stems and roots (Cooper et al., 1988; Fagerness et al., 2004). Since the storage of carbohydrates is the greatest during periods of TE-induced shoot growth suppression (Han et al., 1998; Hull, 1992), these additional carbohydrates may be used for enhancing root or tiller growth. Ervin and Koski (1998) reported that tiller production in perennial ryegrass (Lolium perenne L.) treated with TE increased by $67.9 \%$ compared with the non-treated control. Similar results were reported by Qian and Engelke (1999) in zoysiagrass grown in a shade environment. The increase in tiller production could be a result of the increase in photoassimilates available and cytokinin levels (Ervin and Zhang, 2007; Rajala and PeltonenSainio, 2001). A further benefit of increased tillerring due to TE may improve traffic tolerance. Traffic causes direct pressure to plant tissues that crush and tear the leaves, stems, and crowns in concentrated traffic areas (Beard, 2005). Traffic also causes wear injury to aboveground plant parts and soil compaction (Carrow and Petrovic, 1992). Anatomical, morphological, and physiological characteristics could be attributed to a species ability to tolerate traffic stress (Brosnan et al., 2005). Any management practice that increases the aboveground plant parts and root density of a turf increases the probability of tolerance to traffic stress (Carrow and Wiecko, 1989).

We hypothesized that TE-induced reductions in shoot growth may result in increased tillering and rooting. We further hypothesized that tillering and rooting increases may result in improved traffic tolerance.

The objectives of this study were: 1) to investigate the extent and duration of TE-induced shoot growth suppression on perennial ryegrass and determine any interactive effects that traffic may have on such suppression, 2) to investigate extent and duration of TE-induced physiological responses in perennial ryegrass (carbohydrate content and chlorophyll concentrations), and 3) to investigate if TE-induced reductions in shoot growth affect tillering, and quality of perennial ryegrass, and determine any interactive effects that traffic may have on these performance variables.

\section{Materials and Methods}

Field experiments were conducted on perennial ryegrass at the Isfahan University of Technology Research Center, Isfahan, Iran from July to November 2010. The Research Center is located $1500 \mathrm{~m}$ above sea level. The climate is semiarid with average annual precipitation of $122.8 \mathrm{~mm}$, average annual maximum and minimum temperatures of 23.4 and $9.1^{\circ} \mathrm{C}$, respectively. The soil texture was clay with a pH of 7.9 and an organic matter content of $0.37 \%$ (Table 1). Experimental site was planted with seeds of Lolium perenne L. 'Capri' and 'Numan' (Mommersteeg International B.V., Advanta Seeds West, Netherland). Plots were seeded at a rate of $25 \mathrm{~g} \cdot \mathrm{m}^{-2}$ of pure live seed on 25 April 2010. Germination occurred on 29 April 2010. Prior to and throughout the experiment. The sites received normal maintenance in respect to mowing, fertilization and weed control. Plots were mowed using a reel-type mower at $5-\mathrm{cm}$ mowing height bi-weekly during peak growth. Irrigation was applied as needed to prevent any drought stress for the duration of the experiment. After turf establishment, this experiment was conducted in a split plot design arranged in a randomized complete block (RCB) design with three concentrations $\left(0.00,0.25\right.$, and $0.50 \mathrm{~kg}$ a.i. ha $\left.{ }^{-1}\right)$ of Trinexapacethyl (TE, Syngenta Crop Protection, Greensboro, NC, USA) and three replications. The experimental blocks were 2 $\mathrm{m} \times 9 \mathrm{~m}$ and each block contained 6 experimental units. TE was applied to the main plots $(3 \mathrm{~m} \times 2 \mathrm{~m})$ three times in a year at six-week intervals between July and November (July $3^{\text {rd }}$, August $18^{\text {th }}$, and September $29^{\text {th }}$ ), 2010. TE was applied with a sprayer at a pressure of $242 \mathrm{kPa}$ and a spray volume of $0.1 \mathrm{~L} \cdot \mathrm{m}^{-2}$. All plots received applications of urea $(46 \mathrm{~N}-0 \mathrm{P}-0 \mathrm{~K})$ and was applied by hand at $5 \mathrm{~g} / \mathrm{m}^{2}$, once every 4 weeks beginning at seeding and until end of experiment. Artificial traffic was applied to sub-plots $(3 \mathrm{~m} \times 1 \mathrm{~m})$. Simulated traffic treatment was applied to one half of each main plot with a $150 \mathrm{~kg}, 70-\mathrm{cm}$ wide turf roller modified by bolting rubber soccer cleat soles to the roller (Ervin and Koski, 2001). Traffic treatments began on 7 July 2010 with each plot receiving 70 passes per week during the TE application cycles with the cleated

Table 1. Physical and chemical characteristics of the soil used for growing Lolium perenne.

\begin{tabular}{lcccccc}
\hline Sand (\%) & Silt (\%) & Clay (\%) & Soil texture & Organic matter $(\%)$ & $\mathrm{pH}$ & $\mathrm{EC}\left(\mathrm{dS} \cdot \mathrm{m}^{-1}\right)$ \\
\hline 19 & 36 & 45 & clay & 0.37 & 7.90 & 1.55 \\
\hline
\end{tabular}


roller.

Turf color was visually rated weekly on a 1 to 9 scale with 1 equal to brown turf and 9 equal to dark green color turf following NTEP. Visual turf quality was rated using a scale of 1 to 9 , where $1=100 \%$ dead turf, $9=$ optimum quality, and $6=$ minimal acceptable quality. Clippings were harvested weekly (at $4 \mathrm{~cm}$ height) with a rotary mower. Clippings were oven dried at $70^{\circ} \mathrm{C}$ for $48 \mathrm{~h}$ and, then, weighed. Tiller production (tiller counts per plant) was assessed by recording tiller counts at 4 and 17 weeks after initial TE treatments. A tiller counts sampling tool $15 \mathrm{~cm}$ $\times 5 \mathrm{~cm}$ ) was used to obtain two $25 \mathrm{~cm}^{2}$ subsamples per experimental unit. The verdure of each subsample was separated from the soil; the number of tillers per plant was counted by hand. Turfgrass cover percentage (TCP) was recorded at 10,14, and 18 weeks after initial TE treatments and was rated on a 1 to 9 scale, where 1 represents bare soil and 9 represents 100\% perennial ryegrass cover (Deaton, 2009). The leaf width was determined by measuring 20 leaves in each plot with a micrometer. Canopy (shoot) height was determined by measuring a 10 point sampling in each experimental unit with a floating disk ruler every week after the treatment. Total carbohydrates were measured by sulfuric acid and phenol method (Nielsen, 2010). Chlorophyll and carotenoid concentrations $\left(\mathrm{mg} \cdot \mathrm{g}^{-1}\right.$ fresh clipping weight) were determined at 3, 9, and 15 weeks after initial TE treatments with spectrophotometer (Lichtenthaler and Buschmann, 2001).

Data obtained from this study were analyzed using SAS software Ver.9.1. (SAS Institute, 2003), comparison of means was done by the Least Significant Difference (LSD) test at $5 \%$ probably level.

\section{Results and Discussion}

\section{Canopy Height}

Data analysis showed that turf height was influenced by different treatments of TE, traffic, and interactions between them $(p \leq 0.01)$. This result showed that sequential TE application significantly reduced canopy height of perennial ryegrass (Fig. 1). Growth suppression was evident for 4 weeks after each TE application. Decreasing height began one week after treatment. Maximum canopy height reductions were about 59 and $65 \%$ for 0.25 and $0.5 \mathrm{~kg}$ a.i. ha ${ }^{-1} \mathrm{TE}$, respectively, measured at 2,8 , and 14 WAT. Increased application rate of TE $\left(0.50 \mathrm{~kg}\right.$ a.i. ha $\left.{ }^{-1}\right)$ did not translate into greater suppression levels or longer durations of growth inhibition compared with $0.25 \mathrm{~kg}$ a.i. $\mathrm{ha}^{-1}$ rate. There was no indication of significant post-inhibition-growth enhancement
(PIGE). Concerning the effect of traffic treatment on canopy height, results showed that traffic treatment consistently decreased canopy height compared with control plants. Decreasing height mostly occurred by increasing traffic. More height reduction by traffic was observed in the TE treated turfgrass (Fig. 1). The two-way interaction of TE $\times$ traffic was significant, most likely because of the large and perhaps overriding effect of traffic. Reductions in canopy heights as a result of TE applications were expected because these effects have been detailed in previous reports. Coolseason grass growth reduction by TE has shown by previous researchers (Ervin and Koski, 2001; Fan et al., 2009; Heckman et al., 2005), which are in agreement with the results of this study.

The mode of action for TE involves accumulation at the intercalary meristems region, subsequent interference with GA biosynthesis, and reducing cell elongation in leaves (Kaufmann, 1986). Furthermore, TE treated plants are mainly associated with shorter internode distances and lower vertical growth as compared to control plants. Fan et al. (2009) reported that TE applications in spring and autumn decreased turfgrass growth and reduced mowing frequency. Results from this experiment demonstrated the benefits of sequential applications of TE for inhibition of perennial ryegrass growth. Therefore, a better management strategy for growth inhibition in perennial ryegrass could be sequential TE applications at four-week intervals. Plant growth response to TE was affected by application date, with a shorter duration of suppression for the first TE application compared to the second and the third applications (Fig. 1). Previous researches, studying TE applications on turfgrasses have shown increased TE efficacy at cooler

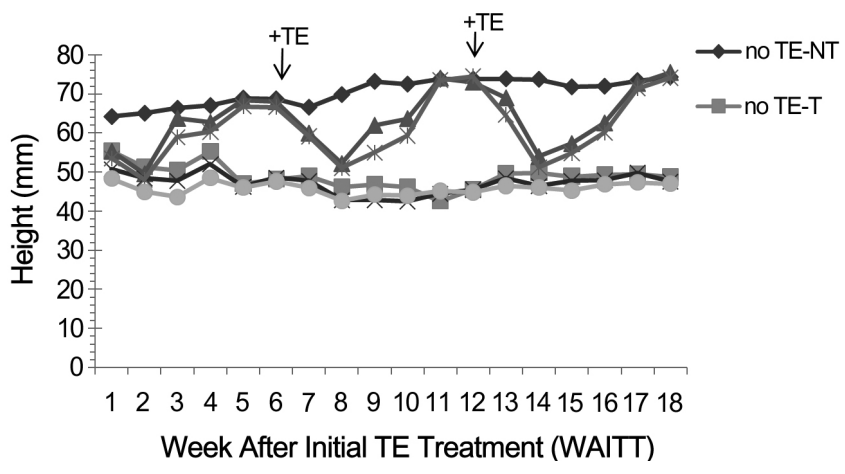

Fig. 1. Effects of trinexapac-ethyl (TE) and traffic (T) on canopy height in perennial ryegrass. All rates of TE are expressed in $\mathrm{kg}$ a.i. ha ${ }^{-1}$ with a repeated application at 6 weeks after initial treatment. +TE: Application of trinexapac-ethyl $\left(\mathrm{LSD}_{0.05}\right.$ $=3.761$ ). 
temperatures (Beasley, 2005; Fagerness et al., 2002; Lickfeldt et al., 2001) and reversely decreased TE efficacy at warmer temperature which was associated with an accelerated rate of TE metabolism in the former (Beasley, 2005).

\section{Turf Color}

The results showed that TE treatment and TE $\times$ traffic did not influence turf color. However, turf color was significantly affected by traffic treatment $(p \leq 0.05)$ (Table 2). Our findings showed that traffic resulted in decreased turf color compared with the control (without traffic). In this study, although in some cases turfgrass color was improved in TE-treated plants compared with the non-treated control,

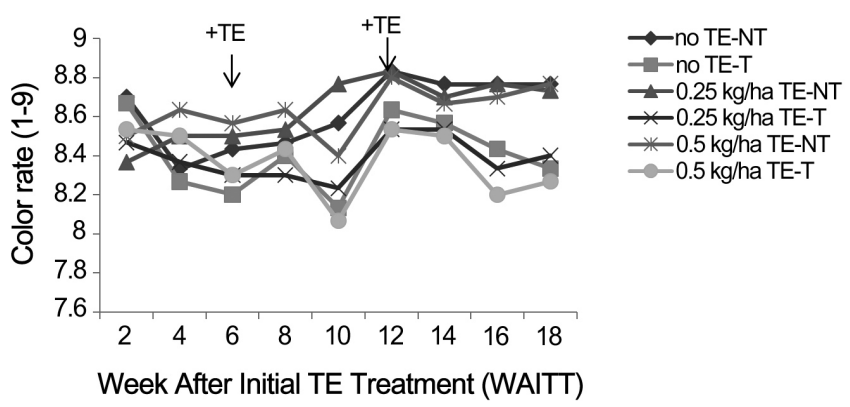

Fig. 2. Effects of trinexapac-ethyl (TE) and traffic (T) on turf color in perennial ryegrass. Turf color was rated on a 1 to 9 scale with 9 equal to dark green turf and 1 equal to brown turf. +TE: Application of trinexapac-ethyl $\left(\mathrm{LSD}_{0.05}=\right.$ $0.18)$.

Table 2. Effects of trinexapac-ethyl (TE) and traffic on perennial ryegrass cover percentage.

\begin{tabular}{lcccccc}
\hline Treatments & & & \multicolumn{3}{c}{ Turf cover percentage } \\
\cline { 1 - 2 } \cline { 5 - 7 } TE $\left(\mathrm{kg} \cdot \mathrm{ha}^{-1}\right)$ & Traffic (T) & & $10 \mathrm{WAT}^{\mathrm{z}}$ & $14 \mathrm{WAT}$ & $18 \mathrm{WAT}$ \\
\hline 0 & No & & $93.30 \mathrm{a}^{\mathrm{y}}$ & $98.51 \mathrm{a}$ & $95.55 \mathrm{a}$ \\
0 & Yes & & $90.00 \mathrm{a}$ & $84.33 \mathrm{a}$ & $75.40 \mathrm{a}$ \\
0.25 & No & & $94.81 \mathrm{a}$ & $97.40 \mathrm{a}$ & $98.14 \mathrm{a}$ \\
0.25 & Yes & & $87.03 \mathrm{a}$ & $85.30 \mathrm{a}$ & $76.54 \mathrm{a}$ \\
0.50 & No & & $95.18 \mathrm{a}$ & $95.55 \mathrm{a}$ & $95.55 \mathrm{a}$ \\
0.50 & Yes & & $85.55 \mathrm{a}$ & $83.30 \mathrm{a}$ & $77.43 \mathrm{a}$
\end{tabular}

Source of variation

\begin{tabular}{lccc}
$\mathrm{TE}$ & $\mathrm{NS}$ & $\mathrm{NS}$ & $\mathrm{NS}$ \\
$\mathrm{T}$ & $* *$ & $* *$ & $* *$ \\
$\mathrm{TE} \times \mathrm{T}$ & $\mathrm{NS}$ & $\mathrm{NS}$ & $\mathrm{NS}$ \\
\hline
\end{tabular}

${ }^{\mathrm{z}}$ WAT: weeks after initial TE treatment.

${ }^{\mathrm{y}}$ Means followed by the same letter are not significantly different as determined by protected LSD ( $p \leq 0.05$ ).

$\mathrm{NS}^{*, * * *}$ Non-significant or significant at $p=0.05$ or 0.01 probability level. this difference was not significant (Fig. 2). Inhibition of leaf expansion has been shown to increase mesophyll cell density and chlorophyll concentration, resulting in dwarfed shoots that enhanced turfgrass color and quality (Ervin and Koski, 2001; Heckman et al., 2005; McCullough et al., 2006a).

\section{Turfgrass Cover Percentage (TCP)}

The effects of TE were insignificant in turf cover percentage (TCP). TCP data indicated significant differences due to the main effects of traffic. Traffic effectively reduced TCP of perennial ryegrass at 10,14, and 18 WAT (Table 2). Turfgrass cover declined almost equally over the course of the application of traffic treatments for TE treated and untreated plots. Sakr (2009) reported that spraying Paspalum vaginatum with TE increased turf density, as compared with the untreated plants. Using both TE concentrations (200 and $400 \mathrm{mg} \cdot \mathrm{L}^{-1}$ ) significantly increased turf density as compared to the control plants.

\section{Tiller Production}

Tiller production per plant increased by TE applications. Minimum tiller production was observed in the control treatment and this indicated that applying TE on the turf significantly increased tiller production. However, nonsignificant differences were observed between 0.25 and $0.50 \mathrm{~kg} \cdot \mathrm{h}^{-1}$ of TE. Traffic treatment had significantly thinned

Table 3. Effects of trinexapac-ethyl (TE) and traffic on perennial ryegrass tillering per plant.

\begin{tabular}{lcccc}
\hline \multicolumn{2}{l}{ Treatments } & & \multicolumn{2}{c}{ Tillering per plant } \\
\cline { 1 - 2 } \cline { 4 - 5 } TE $\left(\mathrm{kg} \cdot \mathrm{ha}^{-1}\right)$ & Traffic $(\mathrm{T})$ & & $4 \mathrm{WAT}^{\mathrm{z}}$ & $16 \mathrm{WAT}$ \\
\hline 0.00 & No & & $1.38 \mathrm{~b}^{\mathrm{y}}$ & $1.61 \mathrm{~b}$ \\
0.00 & Yes & & $1.09 \mathrm{c}$ & $1.18 \mathrm{~d}$ \\
0.25 & No & & $1.45 \mathrm{ab}$ & $1.99 \mathrm{a}$ \\
0.25 & Yes & & $1.36 \mathrm{~b}$ & $1.45 \mathrm{bc}$ \\
0.50 & No & & $1.55 \mathrm{a}$ & $2.03 \mathrm{a}$ \\
0.50 & Yes & & $1.39 \mathrm{~b}$ & $1.42 \mathrm{c}$ \\
Source of variation & & & \\
TE & & & $* *$ \\
T & & $* *$ & $* *$ \\
TE $\times \mathrm{T}$ & & $\mathrm{NS}^{\ddagger}$ & NS \\
\hline
\end{tabular}

${ }^{\mathrm{z}}$ WAT: weeks after initial TE treatment.

${ }^{\mathrm{y}}$ Means followed by the same letter in a column are not significantly different as determined by protected LSD ( $p \leq$ 0.05 ).

${ }_{\text {NS, }}^{* * *}$ Non-significant or significant at $p=0.05$ or 0.01 probability level. 
perennial ryegrass tiller density (Table 3). Tiller production increased by TE application; these results are in agreement with the findings of other researchers (Ervin and Koski, 1998; Fagerness et al., 2002; Qian and Engelke, 1999; Rajala and Peltonen-Sainio, 2001) who found that application of TE increased turf density of treated turfgrasses compared with the control. The increase in the number of tillers as a result of using TE may be attributed to the role of these

Table 4. Effects of trinexapac-ethyl (TE) and traffic on perennial ryegrass leaf width.

\begin{tabular}{lcccccc}
\hline Treatments & & & \multicolumn{3}{c}{ Leaf width $(\mathrm{mm})$} \\
\cline { 1 - 2 } \cline { 5 - 7 } TE $\left(\mathrm{kg} \cdot \mathrm{ha}^{-1}\right)$ & Traffic $(\mathrm{T})$ & & $3 \mathrm{WAT}^{\mathrm{z}}$ & 9 WAT & 15 WAT \\
\hline 0 & No & & $1.86 \mathrm{c}^{\mathrm{y}}$ & $1.86 \mathrm{c}$ & $1.96 \mathrm{a}$ \\
0 & Yes & & $1.93 \mathrm{bc}$ & $1.96 \mathrm{bc}$ & $2.05 \mathrm{a}$ \\
0.25 & No & & $1.94 \mathrm{a}-\mathrm{c}$ & $1.98 \mathrm{bc}$ & $1.98 \mathrm{a}$ \\
0.25 & Yes & & $1.97 \mathrm{a}-\mathrm{c}$ & $1.98 \mathrm{bc}$ & $2.03 \mathrm{a}$ \\
0.50 & No & & $2.07 \mathrm{a}$ & $2.11 \mathrm{a}$ & $2.02 \mathrm{a}$ \\
0.50 & Yes & & $2.02 \mathrm{ab}$ & $2.01 \mathrm{ab}$ & $2.08 \mathrm{a}$
\end{tabular}

Source of variation

\begin{tabular}{llll}
$\mathrm{TE}$ & NS & $*$ & NS \\
$\mathrm{T}$ & NS & NS & NS \\
$\mathrm{TE} \times \mathrm{T}$ & NS & NS & NS \\
\hline
\end{tabular}

${ }^{\mathrm{z}}$ WAT: weeks after initial TE treatment.

${ }^{\mathrm{y}}$ Means followed by the same letter in a column are not significantly different as determined by protected LSD ( $p \leq$ $0.05)$.

${ }_{\text {NS, }}^{* * * *}$ Non-significant or significant at $p=0.05$ or 0.01 probability level. growth regulators in increasing available photoassimilates and cytokinin levels which enhanced cell division involved in the initiation and growth of new tillers from auxiliary meristems, consequently increasing tillering in turfgrasses (Ervin and Zhang, 2007; Pessarakli, 2008; Rajala and Peltonen-Sainio, 2001). Ervin and Koski (1998) reported that tiller production in perennial ryegrass (Lolium perenne L.) treated with TE increased by $67.9 \%$ compared with the non-treated control.

\section{Leaf Width}

Leaf width in $0.50 \mathrm{~kg} \cdot \mathrm{h}^{-1}$ concentration of TE significantly increased compared with the control (Table 4). Jeffrey and Branham (2007) reported that Kentucky bluegrass treated with TE and paclobutrazol (PAC) resulted in decreased leaf area early during inhibition followed by an increased rate of leaf area compared to controls and plant leaf area was increased by 13 or 25 percent of the control for TE- or PAC-treated plants, respectively. Fan et al. (2009) reported that TE application enhanced Kentucky bluegrass (Poa pratensis L.) leaf width in both spring and autumn experimental periods. They also showed that the wider leaf turfgrass made the turf look denser and stronger than the control treatments.

\section{Visual Turf Quality}

Visual turf quality is a rating that integrates numerous turf characteristics including color, uniformity, texture, and density (Skogley and Sawyer, 1992). The main effect of traffic was statistically significant across all observation

Table 5. Effects of trinexapac-ethyl (TE) and traffic on perennial ryegrass visual quality.

\begin{tabular}{|c|c|c|c|c|c|c|c|c|c|c|}
\hline \multicolumn{2}{|l|}{ Treatments } & \multicolumn{9}{|c|}{ Visual quality (1-9) } \\
\hline TE $\left(\mathrm{kg} \cdot \mathrm{ha}^{-1}\right)$ & Traffic (T) & $2 \mathrm{WAT}^{\mathrm{z}}$ & 4 WAT & 6 WAT & 8 WAT & 10 WAT & 12 WAT & 14 WAT & 16 WAT & 18 WAT \\
\hline 0 & No & $7.73 b^{y}$ & $7.72 \mathrm{ab}$ & $8.10 \mathrm{a}$ & $7.57 \mathrm{a}$ & $7.98 \mathrm{a}$ & $7.77 \mathrm{a}$ & $7.73 \mathrm{a}$ & $8.05 \mathrm{a}$ & $8.77 \mathrm{a}$ \\
\hline 0 & Yes & $7.13 \mathrm{c}$ & $6.87 \mathrm{ab}$ & $6.20 \mathrm{bc}$ & $6.07 \mathrm{~b}$ & $5.65 \mathrm{~b}$ & $5.77 \mathrm{~b}$ & $5.23 \mathrm{~b}$ & $4.94 \mathrm{~b}$ & $4.40 \mathrm{~b}$ \\
\hline 0.25 & No & $8.67 \mathrm{a}$ & $7.85 \mathrm{ab}$ & $8.03 \mathrm{a}$ & $8.63 \mathrm{a}$ & $8.37 \mathrm{a}$ & $8.40 \mathrm{a}$ & $8.83 \mathrm{a}$ & $8.58 \mathrm{a}$ & $8.73 \mathrm{a}$ \\
\hline 0.25 & Yes & $7.73 \mathrm{~b}$ & $6.60 \mathrm{~b}$ & $6.37 \mathrm{a}-\mathrm{c}$ & $6.17 \mathrm{~b}$ & $5.80 \mathrm{~b}$ & $5.67 \mathrm{~b}$ & $5.53 \mathrm{~b}$ & $5.10 \mathrm{~b}$ & $4.40 \mathrm{~b}$ \\
\hline 0.50 & No & $8.53 \mathrm{a}$ & $8.03 \mathrm{a}$ & $7.97 \mathrm{ab}$ & $8.20 \mathrm{a}$ & $8.41 \mathrm{a}$ & $8.30 \mathrm{a}$ & $8.67 \mathrm{a}$ & $8.55 \mathrm{a}$ & $8.76 \mathrm{a}$ \\
\hline 0.50 & Yes & $7.37 \mathrm{bc}$ & $6.87 \mathrm{ab}$ & $6.23 \mathrm{c}$ & $6.10 \mathrm{~b}$ & $5.86 \mathrm{~b}$ & $5.87 \mathrm{~b}$ & $5.67 \mathrm{~b}$ & $4.97 \mathrm{~b}$ & $4.27 \mathrm{~b}$ \\
\hline \multicolumn{11}{|c|}{ Source of variation } \\
\hline $\mathrm{TE}$ & & NS & NS & NS & NS & NS & NS & NS & NS & NS \\
\hline $\mathrm{T}$ & & $* *$ & $*$ & $* *$ & $* *$ & $* *$ & $* *$ & $* *$ & $* *$ & $* *$ \\
\hline $\mathrm{TE} \times \mathrm{T}$ & & NS & NS & NS & NS & NS & NS & NS & NS & NS \\
\hline
\end{tabular}

${ }^{\mathrm{z}}$ WAT: weeks after initial TE treatment.

${ }^{\mathrm{y}}$ Means followed by the same letter in a column are not significantly different as determined by protected LSD ( $p \leq 0.05$ ).

$\mathrm{NS}^{*, * *}$ Non-significant or significant at $p=0.05$ or 0.01 probability level. 
dates (Table 5). Regardless of traffic treatment, plots treated with TE exhibited higher visual quality two to four weeks after TE application than untreated plots. However, no significant effect from TE applications was observed in any observation (Table 5). There was no significant traffic by TE interactions observed in visual turf quality. Enhanced turf quality following TE applications is most likely a function of enhanced color and tiller density. McCullough et al. (2006a) reported that repeated TE applications typically enhanced turf color, quality, and tiller density four to eight weeks after initial TE application.

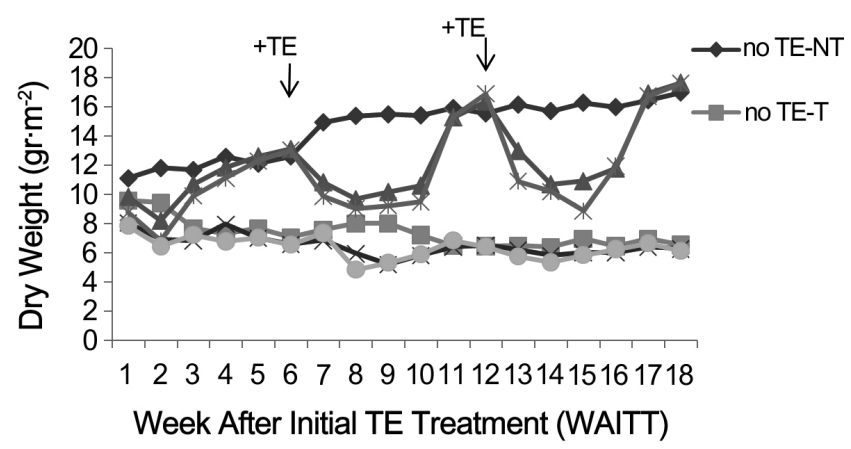

Fig. 3. Effects of trinexapac-ethyl (TE) and traffic (T) on clipping dry weight in perennial ryegrass. All rates of TE are expressed in $\mathrm{kg}$ a.i. $\mathrm{ha}^{-1}$ with a repeated application at 6 weeks after initial treatment. +TE: Application of trinexapac-ethyl $\left(\mathrm{LSD}_{0.05}\right.$ $=1.565)$.

\section{Clipping Dry Weights}

Data analysis presented in Table 2 showed that clippings dry weight was influenced by treatments of TE, traffic, and interactions between them $(p<0.01)$. This result showed that TE application decreased turfgrass dry weight for four weeks after each TE treatment. Decreasing dry weight began in one week after each TE treatment. Maximum decrease in dry weight occurred in the second week after each TE treatment. Traffic treatment decreased clippings dry weight compared with the control treatment. Decreasing dry weight mostly occurred by increasing traffic. In the TE treated turfgrass, higher decrease in dry weight was observed by traffic (Fig. 3). The results of this experiment showed that application of TE significantly decreased clippings dry weight. This finding is in agreement with other research reports (Ervin and Koski, 2001; Fagerness et al., 2002; McCullough et al., 2006b). McCullough (2005) reported that 38 to $75 \%$ shoot weight reduction occurred by TE applications in bermudagrass (Cynodon spp. L. C. Rich). McCullough et al. (2006b) showed that clipping content reduced by TE treatment in 'TifEagle' bermudagrass. Decreasing dry weight of turfgrass was expected by $\mathrm{TE}$, because clipping content would be lower by reduced cell elongation and plant growth.

\section{Chlorophyll and Carotenoid Contents}

Table 5 shows chlorophyll content was significantly affected by TE treatment in the second and the third application

Table 6. Effects of trinexapac-ethyl (TE) and traffic on perennial ryegrass chlorophylls and carotenoids contents.

\begin{tabular}{|c|c|c|c|c|c|c|c|c|c|c|c|c|c|}
\hline \multicolumn{2}{|c|}{ Treatments } & \multicolumn{3}{|c|}{$\begin{array}{c}\text { Total Chl. }^{\mathrm{z}} \\
\left(\mathrm{mg} \cdot \mathrm{g}^{-1} \text { fresh mater) }\right.\end{array}$} & \multicolumn{3}{|c|}{$\begin{array}{c}\text { Chl. } a \\
\left(\mathrm{mg} \cdot \mathrm{g}^{-1} \text { fresh mater) }\right.\end{array}$} & \multicolumn{3}{|c|}{$\begin{array}{c}\text { Chl. } b \\
\left(\mathrm{mg} \cdot \mathrm{g}^{-1} \text { fresh mater }\right)\end{array}$} & \multicolumn{3}{|c|}{$\begin{array}{c}\text { Carot. } \\
\left(\mathrm{mg} \cdot \mathrm{g}^{-1} \text { fresh mater }\right)\end{array}$} \\
\hline $\begin{array}{l}\text { TE } \\
\left(\mathrm{kg} \cdot \mathrm{ha}^{-1}\right)\end{array}$ & $\begin{array}{l}\text { Traffic } \\
\text { (T) }\end{array}$ & $3 \mathrm{WAT}^{\mathrm{y}}$ & 9 WAT & 15 WAT & 3 WAT & 9 WAT & 15 WAT & 3 WAT & 9 WAT & 15 WAT & 3 WAT & 9 WAT & 15 WAT \\
\hline 0.00 & No & $2.16 \mathrm{a}^{\mathrm{x}}$ & $2.40 \mathrm{ab}$ & $2.14 \mathrm{c}$ & $1.58 \mathrm{a}$ & $1.74 \mathrm{a}$ & $1.56 \mathrm{c}$ & $0.58 \mathrm{a}$ & $0.67 \mathrm{~b}$ & $0.58 \mathrm{c}$ & $0.49 \mathrm{a}$ & $0.59 \mathrm{a}$ & $0.57 \mathrm{a}$ \\
\hline 0.00 & Yes & $2.35 \mathrm{a}$ & $2.33 \mathrm{~b}$ & $2.04 \mathrm{c}$ & $1.71 \mathrm{a}$ & $1.68 \mathrm{a}$ & $1.49 \mathrm{c}$ & $0.65 \mathrm{a}$ & $0.65 \mathrm{~b}$ & $0.55 \mathrm{c}$ & $0.54 \mathrm{a}$ & $0.57 \mathrm{a}$ & $0.53 \mathrm{a}$ \\
\hline 0.25 & No & $2.15 \mathrm{a}$ & $2.85 \mathrm{a}$ & $2.49 \mathrm{~b}$ & $1.57 \mathrm{a}$ & $2.01 \mathrm{a}$ & $1.83 \mathrm{~b}$ & $0.58 \mathrm{a}$ & $0.84 a b$ & $0.66 \mathrm{~b}$ & $0.49 \mathrm{a}$ & $0.63 \mathrm{a}$ & $0.58 \mathrm{a}$ \\
\hline 0.25 & Yes & $2.41 \mathrm{a}$ & $2.52 \mathrm{ab}$ & $2.45 \mathrm{~b}$ & $1.76 \mathrm{a}$ & $1.79 \mathrm{a}$ & $1.79 \mathrm{~b}$ & $0.66 \mathrm{a}$ & $0.73 \mathrm{ab}$ & $0.66 \mathrm{~b}$ & $0.57 \mathrm{a}$ & $0.57 \mathrm{a}$ & $0.55 \mathrm{a}$ \\
\hline 0.50 & No & $2.28 \mathrm{a}$ & $2.79 \mathrm{ab}$ & $2.71 \mathrm{a}$ & $1.67 \mathrm{a}$ & $1.79 \mathrm{a}$ & $1.98 \mathrm{a}$ & $0.61 \mathrm{a}$ & $0.99 \mathrm{a}$ & $0.73 \mathrm{a}$ & $0.52 \mathrm{a}$ & $0.52 \mathrm{a}$ & $0.59 \mathrm{a}$ \\
\hline 0.50 & Yes & $2.41 \mathrm{a}$ & $2.76 \mathrm{ab}$ & $2.54 \mathrm{ab}$ & $1.74 \mathrm{a}$ & $1.96 \mathrm{a}$ & $1.86 \mathrm{ab}$ & $0.67 \mathrm{a}$ & $0.79 \mathrm{ab}$ & $0.68 \mathrm{ab}$ & $0.54 \mathrm{a}$ & $0.63 \mathrm{a}$ & $0.53 \mathrm{a}$ \\
\hline \multicolumn{14}{|c|}{ Source of variation } \\
\hline $\mathrm{TE}$ & & NS & * & $*$ & NS & $*$ & * & NS & NS & * & NS & NS & NS \\
\hline $\mathrm{T}$ & & NS & NS & NS & NS & NS & $*$ & NS & NS & NS & NS & NS & $*$ \\
\hline $\mathrm{TE} \times \mathrm{T}$ & & NS & NS & NS & NS & NS & NS & NS & NS & NS & NS & NS & NS \\
\hline
\end{tabular}

${ }^{\mathrm{z}}$ Total Chl.: Total chlorophyll; Chl. a: Chlorophyll $a$; Chl. $b$ : Chlorophyll $b$; Carot.: Carotenoids.

${ }^{\mathrm{y}}$ WAT: weeks after initial TE treatment.

${ }^{\mathrm{x}}$ Means followed by the same letter in a column are not significantly different as determined by protected LSD ( $p \leq 0.05$ )

$\mathrm{NS}^{*, * *}$ Non-significant or significant at $p=0.05$ or 0.01 probability level. 
periods $(p<0.05)$. However, chlorophyll content was not influenced by traffic and there was no interaction between TE and traffic treatment (Table 6). Results showed that not only total chlorophyll content increased by TE application, but also TE enhanced chlorophyll $a$ and chlorophyll $b$ concentrations at 9 and 15 WAT (Table 6). Similar increase in total chlorophyll contents following TE treatments have been reported by other researchers (Heckman et al., 2000; McCullough et al., 2006b; Qian and Engelke, 1999). McCullough et al. (2006b) reported that TE-treated 'TifEagle' bermudagrass had 18\% higher total chlorophyll concentrations than nontreated control plants. Conversely, reduced leaf growth from TE increased chlorophyll concentration per unit of the leaf area. Applications of TE often enhanced turfgrass color and quality from increased cell density and compacted leaf tissue containing greater chlorophyll per unit of the leaf area (Ervin and Koski, 2001; Heckman et al., 2001; Qian and Engelke, 1999). The carotenoid content was not influenced by either traffic or TE treatments during three application periods (Table 6).

\section{Total Carbohydrates (TC)}

TC was significantly affected by TE treatment and traffic $(p<0.01)$ (Table 7). Minimum TC was observed in the control treatment and this indicates that applying TE on

Table 7. Effects of trinexapac-ethyl (TE) and traffic on perennial ryegrass total carbohydrates.

\begin{tabular}{|c|c|c|c|c|}
\hline \multicolumn{2}{|l|}{ Treatments } & \multicolumn{3}{|c|}{$\begin{array}{l}\text { Total carbohydrates } \\
\text { (mg } \cdot \mathrm{g}^{-1} \text { dry mater) }\end{array}$} \\
\hline $\mathrm{TE}\left(\mathrm{kg} \cdot \mathrm{ha}^{-1}\right)$ & Traffic (T) & $3 \mathrm{WAT}^{\mathrm{Z}}$ & 9 WAT & 15 WAT \\
\hline 0.00 & No & $256.3 \mathrm{~b}^{\mathrm{y}}$ & $239.4 \mathrm{c}$ & $270.6 \mathrm{c}$ \\
\hline 0.00 & Yes & $263.0 \mathrm{ab}$ & $260.3 \mathrm{~b}$ & $296.4 \mathrm{ab}$ \\
\hline 0.25 & No & $276.2 \mathrm{a}$ & $263.4 \mathrm{ab}$ & 284.6 bc \\
\hline 0.25 & Yes & $261.1 \mathrm{ab}$ & $271.1 \mathrm{a}$ & $300.4 \mathrm{a}$ \\
\hline 0.50 & No & $276.8 \mathrm{a}$ & $257.9 \mathrm{~b}$ & $283.1 \mathrm{bc}$ \\
\hline 0.50 & Yes & $270.3 \mathrm{ab}$ & $264.2 \mathrm{ab}$ & $296.1 \mathrm{ab}$ \\
\hline
\end{tabular}

Source of variation

\begin{tabular}{lccc}
$\mathrm{TE}$ & $* *$ & $*$ & $\mathrm{NS}$ \\
$\mathrm{T}$ & $\mathrm{NS}$ & $* *$ & $* *$ \\
$\mathrm{TE} \times \mathrm{T}$ & $\mathrm{NS}$ & NS & NS \\
\hline
\end{tabular}

${ }^{\mathrm{z}}$ WAT: weeks after initial TE treatment.

${ }^{\mathrm{y}}$ Means followed by the same letter in a column are not significantly different as determined by protected LSD ( $p \leq$ $0.05)$.

$\stackrel{\mathrm{NS}, * * * *}{N}$ Non-significant or significant at $p=0.05$ or 0.01 probability level. the turf significantly increased TC at 3 and 9 WAT (Table 7). Traffic significantly increased TC in the TE treated and non-treated turf compared with the control. Our results indicate that shoot TC was greater for the plots treated with traffic at 9 and 15 WAT ( 3 weeks after the second and the third applications). Similar increases in the carbohydrates concentration as a result of TE treatments have been reported by Freddie et al. (2005). They showed that TC content of root and shoot tissues in TE treated bermudagrass increased by $38 \%$ and $32 \%$, respectively, compared with non-treated control plants. Ervin and Zhang (2007) showed that greater efficiency of the turfgrass canopy for radiant energy capture in Photosystem II due to TE could imply greater conversion to chemical energy resulting in more net carbohydrate production. Our results indicated that three or more sequential TE applications resulted in more leaf TC. These data and other reports (Ervin and Zhang, 2007; Freddie et al., 2005; Lickfeldt et al., 2001) support the hypothesis that TC may be accumulated more during the period of TE inhibition in order to be used to fuel other sink tissues such as increased tillering, stem growth, or rooting.

Our data demonstrated that three or more sequential TE applications resulted in reduced shoot growth, clipping yield, and post inhibition growth enhancements. Our findings do fully support our hypothesis that reductions in shoot growth due to TE application would result in greater tiller density under non-traffic conditions. Greater tillering due to TE application under continual traffic was not observed, indicating that turf quality was not improved due to TE under traffic. Although traffic adversely affected perennial ryegrass growth and development, TE significantly increased turf quality, tiller counts, chlorophyll $a$ and chlorophyll $b$ contents, and TC content, when compared with non-TE treated plants. On the basis of the results presented here, the possibility of increasing perennial ryegrass traffic tolerance with TE application should not be the main reason for its use, but application of TE for reduced mowing frequency and enhanced turf quality should also be considered.

\section{Conclusions}

To sum up the findings it is suggested that a great influence of TE on improving qualitative and quantitative characteristics of perennial ryegrass. While traffic can diminish the quality of perennial ryegrass, employing TE could not be part of solution. The results clearly demonstrated that TE influence physiological processes of the plant leading to improved quality of turfgrass. However, the exact mechanism 
especially when TE is applied under long-term traffic stress remains to be further investigated.

\section{Literature Cited}

Adams, R., E. Kerber, K. Pfister, and E.W. Weiler. 1992. Studies on the action of the new growth retardant CGA163'935 (cimectacarb), p. 818-827. In: C.M. Karssen, L.C. Van Loon, and D. Vreugdenhil (eds.). Progress in plant growth regulation. Kluwer Academic Publisher, Dordrecht, The Netherlands.

Beard, J.B. 2002. Turfgrass management for golf course. 2th ed., Sleeping Bear Press, Chelsea, MI.

Beasley, J.S. 2005. Physiology and growth responses of cool season turfgrasses treated with trinexapac-ethyl or paclobutrazol. Ph.D. Thesis, University of Illinois, Champaign.

Beasley, J.S. and B.E. Branham. 2007. Trinexapac-ethyl and paclobutrazol affect Kentucky bluegrass single-leaf carbon exchange rates and plant growth. Crop Sci. 47:132-138.

Brosnan, J.T., J.S. Ebdon, and W.M. Dest. 2005. Characteristics in diverse wear tolerant genotypes of Kentucky bluegrass. Crop Sci. 45:1917-1926.

Burpee, L.L., D.E. Green, and S.L. Stephens. 1996. Interactive effects of plant growth regulators and fungicides on epidemics of dollar spot in creeping bentgrass. Plant Dis. 80:1245-1250.

Carrow, R.N. and A.M. Petrovic. 1992. Effects of traffic on turfgrass, p. 285-330. In: D.V. Waddington, R.N. Carrow, and R.C. Shearman (eds.). Turfgrass, Agronomy Monograph 32. ASA, CSSA, and SSSA, Madison, WI.

Carrow, R.N. and G. Wiecko. 1989. Soil compaction and wear stresses on turfgrasses: Future research directions, p. 37-42. In: H. Takatoh (ed.). Proc. of the $6^{\text {th }}$ Int. Turfgrass Res. Conf., Tokyo.

Cooper, R.J., J.R. Street, P.R. Henderlong, and A.J. Koski. 1998. An analysis of the carbohydrate status of mefludide-treated annual bluegrass. Int. Turfgrass Soc. 80:410-414.

Daniels, R.W. and S.K. Sugden. 1996. Opportunities for growth regulation of amenity grass. Pestic. Sci. 47:363-369.

Deaton, M.T. 2009. Trinexapac-ethyl and overseeding effects on shear strength and tolerance to simulated traffic of four bermudagrass cultivars grown on a sand-based system. M.Sc. Thesis, University of Kentucky.

Ervin, E.H. and A.J. Koski. 1998. Growth responses of Lolium perenne L. to trinexapac-ethyl. HortScience 33:1200-1202.

Ervin, E.H. and A.J. Koski. 2001. Trinexapac-ethyl increases Kentucky bluegrass leaf cell density and chlorophyll concentration. HortScience 36:787-789.

Ervin, E.H. and X. Zhang. 2007. Influence of sequential trinexapacethyl applications on cytokinin content in creeping bentgrass, Kentucky bluegrass, and hybrid bermudagrass. Crop Sci. 47: 2145-2152.

Fagerness, M.J., D.C. Bowman, F.H. Yelverton, and T.W. Rufty. 2004. Nitrogen use in Tifway bermudagrass, as affected by trinexapac-ethyl. Crop Sci. 44:595-599.

Fagerness, M.J., F.H. Yelverton, D.P Livingstone, and T.W Rufty. 2002. Temperature and trinexapac-ethyl effects on bermudagrass growth, dormancy, and freezing tolerance. Crop Sci. 42:853-858.

Fan, G., X. Bian, H. Li, Z. Meng, and S.H. Liu. 2009. Growth responses of Kentucky bluegrass (Poa pratensis L.) to trinexapacethyl applied in spring and autumn. Front. Agric. China 3:186-189.

Han, S. and T.W. Fermanian. 1995. Nonstructural carbohydrate flux in 'Penncross' creeping bentgrass treated with plant growth regulators. Agronomy Abstracts. ASA, Madison. p. 160.

Heckman, N.L., T.E. Elthon, G.L. Horst, and R. Gaussoin. 2002. Influence of trinexapac-ethyl on respiration of isolated wheat mitochondria. Crop Sci. 42:423-427.

Heckman, N.L., R.E. Gaussoin, and G.L Horst. 2001. Multiple trinexapac-ethyl applications reduce Kentucky bluegrass sod storage temperatures. HortTechnology 11:595-598.

Heckman, N.L., R.E. Gaussoin, G.L. Horst, and C.G. Elowsky. 2005. Growth regulator effects on cellular characteristics of two turfgrass species. Int. Turfgrass Soc. Res. J. 10:857-861.

Hull, R.J. 1992. Energy relations and carbohydrate partitioning in turfgrasses, p. 175-205. In: D.V. Waddington, R.N. Carrow, and R.C. Shearman (eds.). Turfgrass, Agronomy Monograph 32. ASA, CSSA, and SSSA, Madison, WI.

Kaufmann, J.E. 1986. The role of PGR science in chemical vegetation control. Proc. Plant Growth Regul. Soc. Am. 13:2-14.

Lichtenthaler, H.K. and C. Buschmann. 2001. Extraction of photosynthetic tissues: Chlorophylls and carotenoids. Curr. Protoc. Food Anal. Chem. F4.3.1-F4.3.8

Lickfeldt, D.W., D.S. Gardner, B.E. Branham, and T.B. Voigt. 2001. Implications of repeated trinexapac-ethyl application on Kentucky bluegrass. Agron. J. 93:1164-1168.

McCullough, P.E., H. Liu, and L.B. McCarty. 2005. Response of six dwarf-type bermudagrasses to trinexapac-ethyl. HortScience 40:460-462.

McCullough, P.E., H. Liu, L.B. McCarty, and J.E. Toler. 2006 a. Ethephon and trinexapac-ethyl influence creeping bentgrass growth, quality, and putting green performance. Appl. Turfgrass Sci. 3(1):1-7.

McCullough, P.E., H. Liu, L.B. McCarty, and T. Whitwell. 2004. Response of 'TifEagle' bermudagrass to seven plant growth regulators. HortScience 39:1759-1762.

McCullough, P.E., H. Liu, L.B. McCarty, T. Whitwell, and J.E. Toler. 2006b. Growth and nutrient partitioning of 'TifEagle' bermudagrass as influenced by nitrogen and trinexapac-ethyl. HortScience 41:453-458.

Nabati, D.A., R.E. Schmidt, and D.J. Parrish. 1994. Alleviation of salinity stress in Kentucky bluegrass by plant growth regulators and iron. Crop Sci. 34:198-202.

Nielsen, S.S. 2010. Food analysis laboratory manual. 2th ed., Springer Science, New York, USA.

Pessarakli, M. 2008. Handbook of turfgrass management and physiology. Taylor and Francis, CRC Press, New York. 
Qian, Y.L., M.C. Engelke, M.J.V. Foster, and S. Reynolds. 1998. Trinexapac-ethyl restricts shoot growth and improves quality of 'Diamond' zoysiagrass under shade. HortScience 33:1019-1022.

Rademacher, W. 2000. Growth retardants: Effect of gibberellins biosynthesis and other metabolic pathways. Ann. Rev. Plant Physiol. Plant Mol. Biol. 51:501-531.

Rajala, A. and P. Peltonen-Sainio. 2001. Plant growth regulator effects on spring cereal root and shoot growth. Agron. J. 93:936-943.

Richardson, M.D. 2002. Turf quality and freezing tolerance of 'Tifway bermudagrass as affected by late-season nitrogen and trinexapac ethyl. Crop Sci. 42:162-166.

Sakr, W.R.A. 2008. Response of paspalum turfgrass grown in sandy soil to trinexapac-ethyl and irrigation water salinity. J. Hort. Sci. Ornament. Plants 1:15-20.

SAS Institute. 2003. The SAS system for Windows. Release 9.1. SAS Inst., Cary, NC.

Skogley, C.R. and C.D. Sawyer. 1992. Field research, p. 589-614.
In: D.V. Waddington, R.N. Carrow, and R.C. Shearman (eds.). Turfgrass, Agronomy Monograph 32. ASA, CSSA, and SSSA, Madison, WI.

Stier, J.C., J.N. Rogers, and J.A. Flore. 1997. Nitrogen and trinexapacethyl effects on photosynthesis of Supina bluegrass and Kentucky bluegrass in reduced light conditions. Agronomy Abstracts. ASA, Madison, WI. p. 126.

Tan, Z.G. and Y.L. Qian. 2003. Light intensity affects gibberellic acid content in Kentucky bluegrass. HortScience 38:113-116.

Waltz, F.C. and T. Whitwell. 2005. Trinexapac-ethyl effects on total nonstructural carbohydrates of field grown hybrid bermudagrass. Int. Turfgrass Soc. Res. J. 10:899-903.

Watschke, T.L., M.G. Prinster, and J.M. Breuninger. 1992. Plant growth regulators and turfgrass management, p. 557-588. In: D.V. Waddington, R.N. Carrow, and R.C. Shearman (eds.). Turfgrass, Agronomy Monograph 32. ASA, CSSA, and SSSA, Madison, WI. 